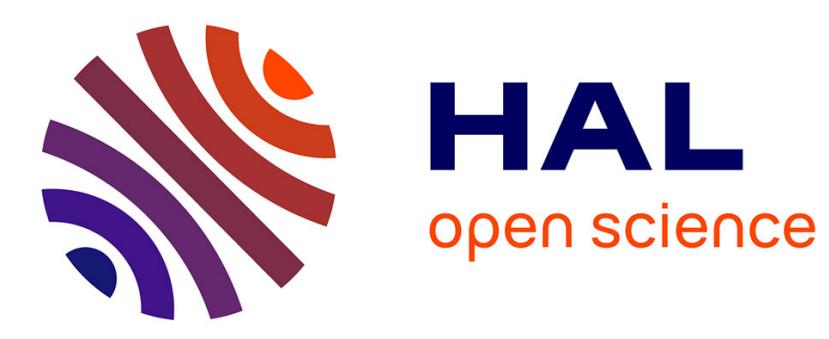

\title{
Hydrolase treatments help unravel the function of intervessel pits in xylem hydraulics
}

Anaïs Dusotoit-Coucaud, Nicole N. Brunel, Aude A. Tixier, Hervé H. Cochard, Stéphane Herbette

\section{- To cite this version:}

Anaïs Dusotoit-Coucaud, Nicole N. Brunel, Aude A. Tixier, Hervé H. Cochard, Stéphane Herbette. Hydrolase treatments help unravel the function of intervessel pits in xylem hydraulics. Physiologia Plantarum, 2014, 150 (3), pp.388-396. 10.1111/ppl.12092 . hal-00964611

\section{HAL Id: hal-00964611 https://hal.science/hal-00964611}

Submitted on 27 May 2020

HAL is a multi-disciplinary open access archive for the deposit and dissemination of scientific research documents, whether they are published or not. The documents may come from teaching and research institutions in France or abroad, or from public or private research centers.
L'archive ouverte pluridisciplinaire HAL, est destinée au dépôt et à la diffusion de documents scientifiques de niveau recherche, publiés ou non, émanant des établissements d'enseignement et de recherche français ou étrangers, des laboratoires publics ou privés. 


\title{
Hydrolase treatments help unravel the function of intervessel pits in xylem hydraulics
}

\author{
Anaïs Dusotoit-Coucaud ${ }^{a, b}$, Nicole Brunel ${ }^{a, b}$, Aude Tixier ${ }^{a, b}$, Hervé Cochard ${ }^{a, b}$ and Stéphane \\ Herbette $^{a, b *}$ \\ aINRA, UMR547 PIAF, 5 Chemin de Beaulieu, 63039, Clermont-Ferrand, Cedex 02, France \\ ${ }^{b}$ Clermont Université, Université Blaise-Pascal, UMR547 PIAF, BP 10448, 63000, Clermont-Ferrand, France
}

\author{
Correspondence \\ *Corresponding author, \\ e-mail: \\ stephane.herbette@univ-bpclermont.fr
}

Received 16 April 2013;

revised 18 June 2013

doi:10.1111/ppl.12092
Intervessel pits are structures that play a key role in the efficiency and safety functions of xylem hydraulics. However, little is known about the components of the pit membrane (PM) and their role in hydraulic functions, especially in resistance to cavitation. We tested the effect of commercial chemicals including a cellulase, a hemicellulase, a pectolyase, a proteinase and DTT on xylem hydraulic properties: vulnerability to cavitation (VC) and conductance. The effects were tested on branch segments from Fagus sylvatica (where the effects on pit structure were analyzed using TEM) and Populus tremula. Cellulose hydrolysis resulted in a sharp increase in VC and a significant increase in conductance, related to complete breakdown of the PM. Pectin hydrolysis also induced a sharp increase in VC but with no effect on conductance or pit structure observable by TEM. The other treatments with hemicellulase, proteinase or DTT showed no effect. This study brings evidence that cellulose and pectins are critical components underpinning VC, and that PM components may play distinct roles in the xylem hydraulic safety and efficiency.

\section{Introduction}

In plants, long-distance sap transport occurs under negative pressures in xylem conduits. Sap flows between adjoining conduits through pits that form pores in the walls and play a key role in the safety and efficiency of the hydraulic system through the xylem (Choat et al. 2008). These pits facilitate the flow of water while preventing the passage of air bubbles. Under water stress conditions, xylem tensions increase and the conduits become vulnerable to cavitation. Cavitation provokes air embolism, leading to a loss of hydraulic conductance that can potentially result in organ or whole-plant death.

Strong correlations have been found between the drought tolerance of a species and its xylem vulnerability to cavitation (VC) (Maherali et al. 2004, Tissier et al.
2004, Choat et al. 2012). Substantial variations have also been found within species, between genotypes or depending on environmental conditions (Cochard et al. 2007, Dalla-Salda et al. 2009, Awad et al. 2010, Herbette et al. 2010, Wortemann et al. 2011). Xylem resistance to cavitation is thus considered a major adaptive trait for tree drought tolerance, and is thought to be one of the most promising criteria for screening for this feature. However, the literature provides only limited insights on the molecular and genetic factors involved.

The most likely mechanism of cavitation would be located on vessel pit (Sperry and Tyree 1988, Cochard 2006). According to the 'air seeding' hypothesis, water stress-induced cavitation would occur when an air bubble passes through a pit membrane (PM) (Cochard et al. 1992, 2009). Hence, VC would be strongly influenced by the porosity of the PM (Sperry and Tyree 1988, Cochard

Abbreviations - DTT, dithiothreitol; $P_{50}$, xylem pressure inducing a $50 \%$ loss of conductance; PM, pit membrane; TEM, transmission electronic microscopy; VC, vulnerability to cavitation. 
2006) and its mechanical properties during the cavitation process (Choat et al. 2004, Sperry and Hacke 2004). Clearly, the structural, physical and chemical properties of the PM are central determinants of cavitation. Pit structure has been the most intensively investigated property to date. Within angiosperms, there is a strong correlation between PM thickness and resistance to cavitation (Jansen et al. 2009, Lens et al. 2011). Pits with thicker PMs have smaller pores and are thought to be mechanically stronger, allowing them to resist air seeding. In conifers, which have pits with a thick torus surrounded by a thin margo, a major character for embolism resistance would be the size ratio of the torus-to-pit aperture diameter (Hacke and Jansen 2009, Pittermann et al. 2010). In contrast with pit structure, our knowledge on PM biochemistry is limited, with contradictory findings in the literature. Insights on PM composition are urgently needed, since it can strongly influence the porosity, permeability and mechanical properties of the PM and the air-water interface in this cavitation process.

PMs are composed of the middle lamella plus the primary walls of adjacent cells that have undergone modifications. This means they would initially be made of tightly interwoven cellulose microfibrils in a matrix of hydrated hemicelluloses and pectins, including various proteins. However, the modifications that occur as the PM matures are unknown. Hydrolysis of the cell wall was observed in PM and this would remove most of the non-cellulosic polysaccharides unprotected by lignins (O'Brien and Thimann 1967, O'Brien 1970, Butterfield and Meylan 1982). Hence, there is ongoing debate on the final composition of a mature pit, especially the presence of pectins and/or hemicelluloses (Zwieniecki et al. 2001, Herbette and Cochard 2010, Plavcova and Hacke 2011), while lignin deposition and protein composition have retained little attention. Studies using staining techniques suggest that the PM contains lignin (Fromm et al. 2003) and pectin (Gortan et al. 2011), whereas others suggest that all but the highly methylated pectins get removed from pit as it matures (Czaninski 1972, 1979, Catesson 1983). Explanations for such discrepancies are the weak specificity and sensitivity of staining techniques and the diverse composition of PMs across species. The ion-mediated water flow variation in xylem observed for several species has been attributed to the hydrogel properties of PM pectins (Zwieniecki et al. 2001, Boyce et al. 2004, Cochard et al. 2010). Although an alternative hypothesis to pectin shrinking has been proposed, there is no experimental evidence for it (van Doorn et al. 2011). Immunolabeling studies in poplar did not detect any pectin in most of the PM but found clusters of pectins in the annulus (Plavcova et al. 2011, Plavcova and Hacke 2011). Immunolabeling has the advantage of bringing direct evidence for the presence of a compound but can be hindered by accessibility to the epitope, especially in cell walls. In other words, no labeling can be explained by either an absence of pectins or by other compounds masking a pectic epitope.

Beyond this debate on the composition of PM, the role of its respective components remains to be addressed, especially in terms of resistance to cavitation. As a first step, we tested the effect of commercial hydrolases including a cellulase, a hemicellulase, a pectolyase and a proteinase on xylem hydraulics properties: VC and conductance. The pit structure was then analyzed by TEM to explain the effect of the hydrolases and propose hypotheses on the role of the respective target components. These investigations were performed on beech, a species in which we had previously demonstrated a role of calcium in VC (Herbette and Cochard 2010), but as the debate on pectin in PM has shifted toward poplar, we also tested the effect of hydrolases on VC for a poplar species.

\section{Materials and methods}

\section{Plant material}

The perfusion experiments were carried out on stems from an old beech tree (Fagus sylvatica) from Allagnat forest in central France $\left(45^{\circ} 45^{\prime} 23^{\prime \prime} \mathrm{N}, 2^{\circ} 56^{\prime} 26^{\prime \prime} \mathrm{E}\right.$, $1000 \mathrm{~m}$ a.s.l.) and on stems from an adult poplar tree (Populus tremula) from Bort-l'Etang in central France $\left(45^{\circ} 47^{\prime} 02^{\prime \prime} \mathrm{N}, 3^{\circ} 25^{\prime} 43^{\prime \prime} \mathrm{E}, 333 \mathrm{~m}\right.$ a.s.l.). Stems were sampled on the same tree to avoid intraspecific variation. Branches were harvested from October to December, i.e. after the vegetative season and before the temperature decrease drastically below $0^{\circ} \mathrm{C}$. We analyzed sunlit shoots of comparable age and growth. Selected stems were $0.5-1 \mathrm{~cm}$ in diameter and $0.5 \mathrm{~m}$ long. The freshly sampled stems were sealed in airtight black plastic bags to reduce water loss through transpiration and taken straight to the lab to measure xylem hydraulic conductance on the same day or the day after. Samples taken to study VC were wrapped in moist paper, bagged and stored at $4{ }^{\circ} \mathrm{C}$ until analysis.

\section{Chemical treatments}

Chemical treatments were applied just prior to hydraulic analysis. Samples were infiltrated under vacuum by connecting their terminal part to a vacuum pump while their base was immersed in a flask containing an excess of solution until at least $5 \mathrm{ml}$ had perfused through the samples. We tested six different chemical treatments: four solutions prepared in $5 \mathrm{mM}$ MES buffer $(\mathrm{pH} 5)$, i.e. MES buffer at $\mathrm{pH} 5$ as control; $1 \% \mathrm{w} / \mathrm{v}$ cellulase 
[1,4-(1,3:1,4)- $\beta$-D-glucan 4-glucano-hydrolase, EC number 3.2.1.4, Sigma-Aldrich, Saint-Quentin Fallavier, France]; $0.1 \% \mathrm{w} / \mathrm{v}$ pectolyase [endopolygalacturonase (EC3.2.1.15) and endopectin lyase (EC4.2.2.10), Sigma-Aldrich], $5.4 \% \mathrm{w} / \mathrm{v}$ hemicellulose [1,4- $\beta$-Dxylanxylanohydrolase, endo-1,4- $\beta$-xylanase, EC3.2.1.8, Sigma-Aldrich] or all three enzymes together, and two solutions prepared in $10 \mathrm{mM}$ Tris- $\mathrm{HCl}$ buffer $(\mathrm{pH} 7.5)$, i.e. Tris- $\mathrm{HCl}$ buffer as control, $20 \% \mathrm{w} / \mathrm{v}$ proteinase K (EC3.4.21, Sigma-Aldrich) or $10 \mathrm{mM}$ DTT (SigmaAldrich). Just prior to solution infiltrations, samples were rinsed with $5 \mathrm{mMMES}$ buffer at $\mathrm{pH} 5$ or $10 \mathrm{mM}$ Tris $-\mathrm{HCl}$ buffer at $\mathrm{pH}$ 7.5. After perfusion, samples were wrapped in moist paper, sealed in a plastic bag and incubated for $2 \mathrm{~h}$ at $37^{\circ} \mathrm{C}$, then rinsed with either the MES buffer or the Tris- $\mathrm{HCl}$ buffer, except for the DTT treatment.

\section{Xylem VC}

Xylem VC was assessed on $0.28 \mathrm{~m}$ long stem samples using the centrifugal technique (Alder et al. 1997, Cochard 2002). The technique uses the centrifugal force to increase water tension in a xylem segment and a XYL'EM apparatus (Bronkhorst, Montigny-lesCormeilles, France) to measure the decrease in hydraulic conductance. Before centrifugation steps, we first determined sample maximal conductance $\left(K_{\max }\right)$ under 6-9 $\mathrm{kPa}$. The stem segments were perfused with a solution containing $10 \mathrm{mM} \mathrm{KCl}$ and $1 \mathrm{mM} \mathrm{CaCl}$. Samples subjected to water tension were then connected to the hydraulic apparatus, and a conductance $(K)$ was measured. Xylem pressure was reset to a more negative pressure, and the new sample conductance $\mathrm{K}$ was determined. Percent loss of conductance (PLC) was then computed as $\mathrm{PLC}=100 \times\left(1-\mathrm{K} / \mathrm{K}_{\max }\right)$. The procedure was repeated for increasingly negative pressures in -0.1 to $-0.5 \mathrm{MPa}$ step increments until PLC reached at least 90\%. Following Pammenter and Vander Willigen (1998), a sigmoid function was fitted to each curve:

$$
\mathrm{PLC}=100 /\left(1+\mathrm{e}^{\mathrm{s}\left(\mathrm{P}-\mathrm{P}_{50}\right) / 25}\right)
$$

where $\mathrm{P}_{50}$ is the pressure causing a $50 \%$ loss in hydraulic conductivity and $s$ is the slope curve at this point.

\section{Xylem hydraulic conductance and embolism rate}

Xylem hydraulic conductance $(\mathrm{K})$ was measured on $0.3 \mathrm{~m}$ long beech stems using the XYL'EM apparatus. Samples were cut under water to avoid air entry. To explore the effect of hydrolases on xylem conductance, samples were first perfused with control solution (MES buffer at $\mathrm{pH}=5$ ) with their distal part connected to the XYL'EM. Initial conductance was measured under 6 to
$9 \mathrm{kPa}$ using the MES buffer. The stems were then perfused with control solution or one of the four enzymatic solutions described above. After incubation, the new conductance was scored and expressed relative to initial conductance. Conductance variations were determined for six to nine stems per treatment. After analysis, samples were wrapped in moist paper, bagged and stored at $4^{\circ} \mathrm{C}$ for further tests on VC.

To check the effects of the enzymes on VC, centrifugeinduced embolism was measured at the sample center. After enzymatic treatments, $0.28 \mathrm{~m}$ long beech segments were submitted to a xylem pressure of $-2.5 \mathrm{MPa}$ using a centrifuge (cavitron). Then, the middle $5 \mathrm{~cm}$ long part of the stem was prepared by cutting underwater. Initial conductivity $\left(\mathrm{K}_{\mathrm{i}}\right)$ was measured using the $\mathrm{XYL^{ \prime }} \mathrm{EM}$ apparatus. A water flush of $0.15 \mathrm{MPa}$ was then applied to the segments for $5 \mathrm{~min}$ to dissolve air bubbles. Hydraulic conductivity was determined again and the flushes were repeated until the maximum conductivity $\left(\mathrm{K}_{\mathrm{m}}\right)$ was reached. The embolism rate (E) was calculated as follows:

$$
\mathrm{E}=100\left(\mathrm{~K}_{\mathrm{m}}-\mathrm{K}_{\mathrm{i}}\right) / \mathrm{K}_{\mathrm{m}}
$$

\section{Transmission electronic microscopy}

After enzymatic treatments, some branches were directly prepared for TEM analysis whereas others were subjected to a xylem pressure of $-4 \mathrm{MPa}$ before being prepared for TEM analysis. Half or quarter sections were taken in the stem center with a clean razor blade. Fragments were cut to a size of about $2 \mathrm{~mm}^{3}$. Fragments were then fixed and included in LR-White resin (Sigma-Aldrich) as described by Jansen et al. (2007). Transverse and $70 \mathrm{~nm}$-thick sections were made with an ultramicrotome (UC6, Leica, France), mounted onto copper grids, stained with uranyl acetate and lead citrate, then observed under a Hitachi H-7650 transmission electron microscope (Hitachi, Elexience, France) and photographed with a CCD AMT HR camera (Hamamatsu, $1024 \times 1024$ pixels).

\section{Cellulase activity assays}

The cellulase activity of the commercial enzymes was tested by measuring reducing sugar release from soluble carboxymethyl cellulose (CMC) (Miller 1959). CMCase activity was determined in a $200 \mu \mathrm{l}$ assay mixture that contained 1\% (w/v) CMC (Sigma-Aldrich) dissolved in $10 \mathrm{mM}$ MES buffer at $\mathrm{pH} 5$. We added $50 \mu \mathrm{l}$ of the enzyme [Pectolyase $0.1 \%(\mathrm{w} / \mathrm{v})$ or hemicellulase $3.7 \%(\mathrm{w} / \mathrm{v})$ or cellulase $0.01 \%(\mathrm{w} / \mathrm{v})]$ dissolved in $10 \mathrm{mM}$ MES buffer at $\mathrm{pH} 5$ prior to incubation at $37^{\circ} \mathrm{C}$ for $2 \mathrm{~h}$. Samples were examined for presence of reducing sugars by the dinitrosalicylic acid method 
(Miller 1959). Controls were run in an identical manner except that the enzyme samples were boiled for $5 \mathrm{~min}$ prior to incubation. The amount of reducing sugars was determined spectrophotometrically by measuring the absorbance of the solution at $530 \mathrm{~nm}$ and comparing the absorbance values against a glucose standard curve.

\section{Statistical analyses}

ANOVA was used to investigate the effects of treatments on VC and on hydraulic conductance. If the effects were significant, mean values were compared using Tukey's Honestly Significant Difference (HSD) test $(P<0.05)$.

\section{Results}

\section{Effect of hydrolase treatments on xylem VC}

Beech or poplar segments infiltrated with different solutions showed highly-contrasted cavitation curves. Xylem vulnerability increased dramatically when segments were infiltrated with cellulase or pectolyase solutions whereas segments infiltrated with hemicellulase solution showed no difference compared to controls (Fig. 1). Mean $P_{50}( \pm \mathrm{SD})$ was $-2.81( \pm 0.42) \mathrm{MPa}$ and -2.48 $( \pm 0.43) \mathrm{MPa}$ for beech and poplar control stems, respectively. These values are consistent with previous reports for both species (Herbette and Cochard 2010, Herbette et al. 2010). After hemicellulose treatments, branches had similar $P_{50}$ values to controls, at $-2.73( \pm 0.64) \mathrm{MPa}$ and $-2.10( \pm 0.30) \mathrm{MPa}$ for beech and poplar, respectively. After cellulase and pectolyase treatments, $P_{50}$ values were $-0.21( \pm 0.04) \mathrm{MPa}$ and $-0.32( \pm 0.01) \mathrm{MPa}$ for beech and $-0.27( \pm 0.02) \mathrm{MPa}$ and $-0.47( \pm 0.10) \mathrm{MPa}$ for poplar, respectively. To confirm that the loss of conductivity was related to cavitation and not to obstruction by enzymes or their degradation products, we measured embolism rate in the center of the treated samples. In beech stems subjected to a xylem pressure of $-2.5 \mathrm{MPa}$, embolism rate was 89 and $100 \%$ in pectolyase- and cellulase-treated samples vs 33 and $38 \%$ in control and hemicellulase-treated samples (data not shown). To verify that the effect of pectolyase was not due to a contaminating cellulase activity, we measured the cellulase activity of the three enzyme solutions (Table 1). The cellulase activity levels found in the cellulase and hemicellulase solutions were consistent with the data given by the supplier, but no information was given for the pectolyase solution. The pectolyase solution showed some cellulase activity but at a significantly lower level than the hemicellulase solution. We can thus conclude that the effect of the pectolyase on the VC was not due to a cellulase activity.

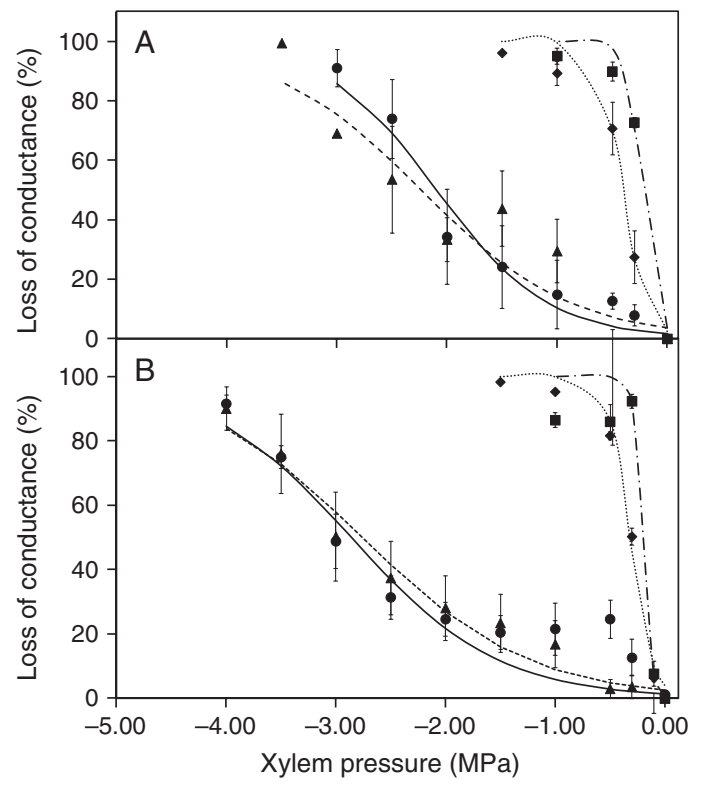

Fig. 1. Vulnerability curves of poplar (A) and beech (B) branches perfused with hydrolases. Branches were perfused with a control solution (circle) or a solution containing cellulase (square), hemicellulase (triangle) or pectolyase (diamond) incubated for $2 \mathrm{~h}$ at $37^{\circ} \mathrm{C}$ and perfused with a solution containing $1 \mathrm{mM} \mathrm{CaCl} 2$ and $10 \mathrm{mM} \mathrm{KCl}$. The vulnerability curves were then established. Data are means $( \pm \mathrm{SE})$ from three to eight samples.

Table 1. Cellulase activity of the hydrolase solutions used for treatments. Solution containing enzymes used for treatment were assayed for their contaminating cellulase activities (see section Materials and methods). The assays were performed on a 100 -fold diluted solution of the cellulase solution, because of the high activity found compared to hemicellulase and pecto-lyase. Data are means values from three replicates ( \pm sE).

\begin{tabular}{lc}
\hline Enzyme (w/v) & $\begin{array}{c}\text { Cellulase activity } \\
\left(\text { units } \mathrm{ml}^{-1} \text { ) }\right.\end{array}$ \\
\hline Cellulase $1 \%$ & $102( \pm 3.57)$ \\
Hemicellulase $3.7 \%$ & $3.03( \pm 0.06)$ \\
Pecto-lyase $0.1 \%$ & $2.50( \pm 0.08)$ \\
\hline
\end{tabular}

Branches infiltrated with DTT or proteinase K solutions showed no effect on VC compared to branches infiltrated with control solution (Fig. 2).

\section{Effect of hydrolase treatments on xylem hydraulic conductance}

Beech branches $(28 \mathrm{~cm}$ long) were infiltrated with control solution, and their hydraulic conductance $\mathrm{K}$ was measured. The branches were then treated with control solution or a solution containing cellulase, hemicellulase or pectolyase, conductance was measured, and the variation was calculated relative to the initial 


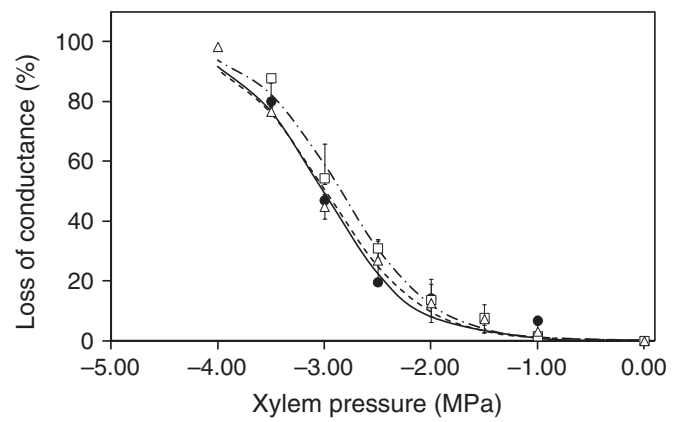

Fig. 2. Vulnerability curves of beech branches perfused with a protease or DTT. Branches were perfused with a control solution (dark circle) or a solution containing proteinase $\mathrm{K}$ (white square) or DTT (white triangle) and incubated for $2 \mathrm{~h}$ at $37^{\circ} \mathrm{C}$. The vulnerability curves were then established. Data are means ( $\mathrm{ISE}$ ) from three samples.

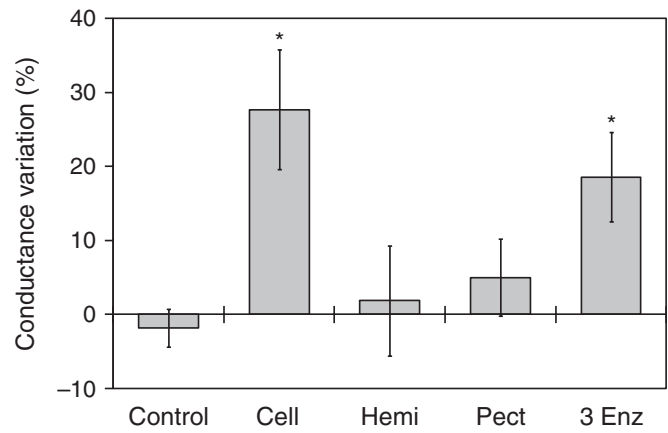

Fig. 3. Effect of hydrolases on xylem conductance. Beech branches were perfused with a control solution, and conductance was scored. The branches were then perfused with a control solution, or with a solution containing cellulase (Cell), hemicellulase (Hemi) or pectolyase (Pect), or a mixture of all three hydrolases (3 Enz), incubated for $2 \mathrm{~h}$ at $37^{\circ} \mathrm{C}$, and perfused with a solution containing $1 \mathrm{mM} \mathrm{CaCl}$ and $10 \mathrm{mM}$ $\mathrm{KCl}$. Then, conductance was scored, and the variation was expressed relative to initial conductance. Data are means ( \pm sE) from six to ten samples. Data highlighted with an asterisk are significantly different from controls according to a Tukey's HSD test $(P<0.05)$.

conductance (Fig. 3). To test for a synergistic effect between the enzymes, we also infiltrated some branches with a solution containing a mix of the three enzymes. Cellulase treatment induced a significant mean $28 \%$ increase in conductance whereas the hemicellulase or pectolyase treatments had no significant effect. The treatment with all three enzymes gave similar results to treatment with cellulase alone.

\section{Effect of hydrolase treatments on PM structure}

To gain insights into the effect of hydrolases on xylem hydraulics, we performed TEM analyses of the xylem structure, focusing on PM structure. These analyses were performed both on branches infiltrated with hydrolases and on branches infiltrated with hydrolases and then submitted to full embolism. Xylem transverse sections showed no observable difference in vessel wall structure between the different treatments, suggesting that the treatments were soft enough to avoid damaging the vessel walls. When infiltrated branches were incubated with cellulase, the PM was either fully stripped or strongly destroyed (Fig. 4B and F), with no effect on pit borders. There was no observable effect on PM following hemicellulase or pectolyase treatment (Fig. 4C, D, G, and H), whether before or after cavitation.

\section{Discussion}

Against a background of ongoing debate over presence of pectins in $\mathrm{PM}$, this study brings evidence that cellulose and pectins are critical components of $\mathrm{VC}$, and that they likely have distinct roles in the efficiency and safety of xylem hydraulics.

\section{Effects of cellulose or pectin hydrolysis on xylem hydraulics}

In a previous study, we infiltrated chemicals through beech branches to investigate the role of calcium in xylem hydraulics (Herbette and Cochard 2010). Here, we used the same methods on the same species to investigate the role of wall components in xylem hydraulics - only lignins could not be investigated as there is no treatment for them. Protein concentration remained unchanged after branch infiltration with solutions containing hydrolytic enzymes (data not shown), indicating that the hydrolases were correctly infiltrated throughout the samples. In support of this, pectolyase or cellulase infiltration strongly increased VC in the sample center (see section Results). We used commercial enzymes that were characterized and already used to investigate physiological functions (Schulte and Gibson 1988, Chappell et al. 1991, Vries and Visser 2001). We used supplier-recommended concentrations for preparing protoplast, and so they were not limiting. We also checked that the pectolyase effect was not due to a contaminating cellulase activity.

The cellulase treatment induced a sharp increase in VC (Fig. 1). This effect has to be related to the PM breakdown whereas the vessel wall remained intact (Fig. 4). According to the "air seeding" hypothesis, xylem cavitation would occur by air aspiration through pores in the PM. VC would thus be a function of the diameter of the largest pore in the PM. In the cellulase-treated branches, the pore for air seeding is the pit aperture. The median aperture diameter of beech pits was $2.16 \mu \mathrm{m}$ (data not shown). According to Laplace's law, the deduced xylem pressure inducing 


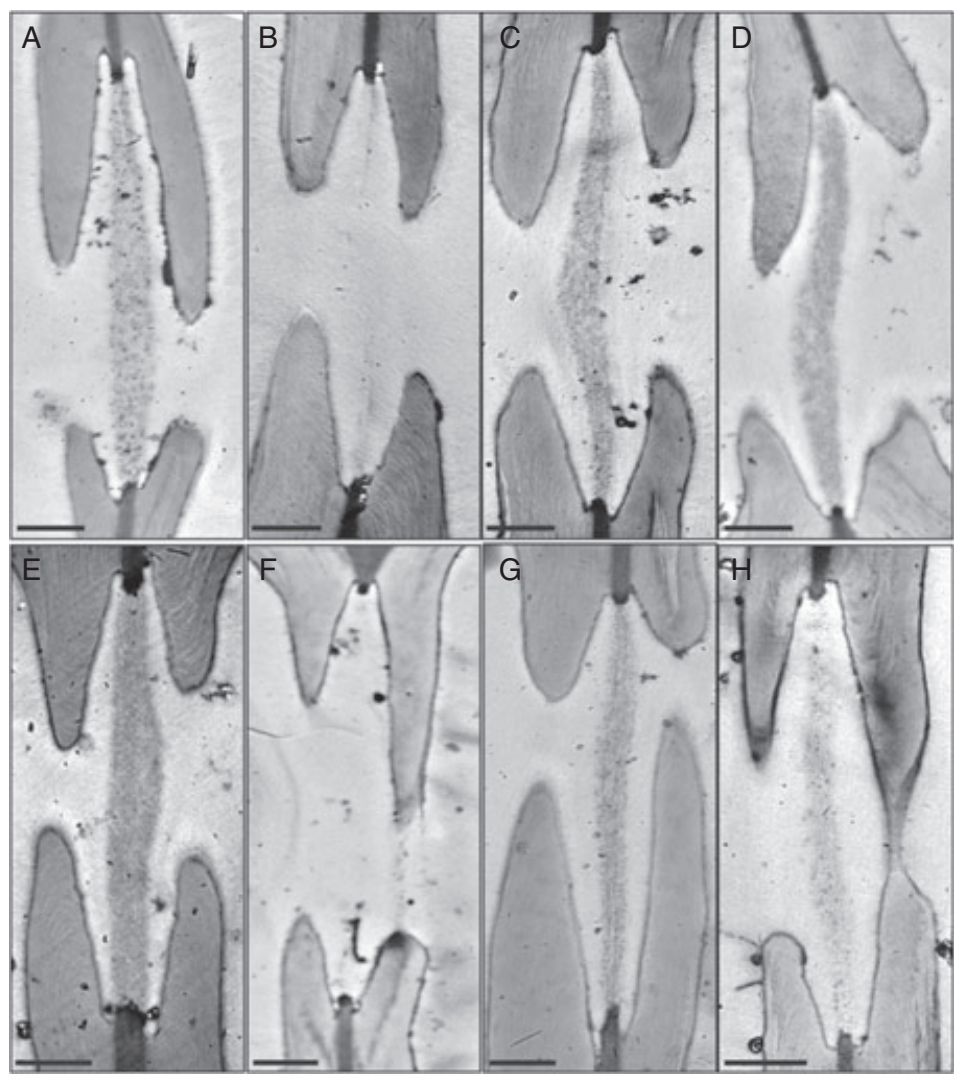

Fig. 4. TEM images of intervessel pit structure of hydrolase-treated branches. All images are from transverse and ultrathin $(70 \mathrm{~nm})$ sections prepared from three branches per treatment. Beech branches were perfused with a control solution ( $A, E)$ or with a solution containing cellulase $(B, F)$, pectolyase $(C, G)$ or hemicellulase $(D, H)$ and incubated for $2 \mathrm{~h}$ at $37^{\circ} \mathrm{C}$. Then, some branches were prepared for TEM analysis (A, D) of their intervessel pits while others were subjected to a xylem pressure of $-4 \mathrm{MPa}$ before being prepared for TEM analysis $(E, H)$. PMs were absent in most of the pit from cellulose-treated branches (B, F). No differences were observed between pits from control branches (A, E) and pits from pectolyase- and hemicellulase-treated branches (C, D, G, H). Scale bar $=1 \mu \mathrm{m}$.

cavitation would thus be $-0.14 \mathrm{MPa}$, in agreement with $P_{50}$ values for these cellulase-treated beech branches. Cellulase-treatment also induced a $28 \%$ increase in xylem conductance in beech branches (Fig. 3) that can be attributed to the removal of PM resistance (Fig. 4). This resistance was previously evaluated on six tracheid-bearing species by dissolving PM with a cellulase (Schulte and Gibson 1988). For these species, PM resistance accounted for 14 up to $84 \%$ of xylem resistance. PM resistance was estimated to account for 80 and $87 \%$ of xylem hydraulic resistance in Ulmus americana and Fraxinus americana, respectively (Choat et al. 2006). This high contribution of PM to resistance is due to the lower lumen resistance of the earlywood vessels in these ring-porous species (Choat et al. 2006). Indeed, these species were selected because the large diameters of earlywood vessels $(60-120 \mu \mathrm{m})$ facilitate their measurements. Values for PM resistance have also been provided by models (Sperry and Hacke 2004) and measurements on progressively shortened stems (Sperry et al. 2005, Wheeler et al. 2005, Hacke et al. 2006). According to these studies, end wall resistivity would average half of the total xylem resistivity, what agrees with the value found for the contribution of the PM alone.

TEM investigations have found cellulose microfibrils in PM in most species (Schmid and Machado 1968, Sperry and Tyree 1988, Sano 2005, Jansen et al. 2009). These studies suggest that cellulose is the PM framework, while our results on two tree species demonstrate that cellulose is critical for PM functions and structure.

The lack of effect on xylem hydraulics with hemicellulase, protease or DTT suggests wall proteins and hemicelluloses do not play important roles in pit hydraulic function. Besides, most hemicelluloses get hydrolyzed in PM as vessels mature ( $\mathrm{O}^{\prime}$ Brien 1970) and so were logically absent in mature PM of the few species investigated (Imamura et al. 1974, Dute et al. 2008, Alves et al. 2009). Although the presence of proteins in PM has still not been specifically addressed, a proline-, threonineand glycine-rich protein has been localized in intervessel 
PM in tomato (Harrak et al. 1999), suggesting a specific role in PM. Lack of effect with DTT or protease treatment suggested that this role would not related to hydraulics.

The hydrolysis of pectins induced a sharp increase in xylem VC for both beech and poplar, with no effect on conductance (Figs 1 and 3). This is consistent with two previous studies demonstrating that calcium is important for resistance to cavitation but not for conductance in beech and poplar (Herbette and Cochard 2010, Plavcova and Hacke 2011). We did not find any clear effect of pectin hydrolysis on the pit or PM structure (Fig. 4), and cellulase-treated samples were more vulnerable to cavitation than pectolyase-treated samples in both species. Pectin hydrolysis and cellulose hydrolysis probably have distinct effects. Furthermore, the presence of pectin in PM is questioned. According to literature reviews (Choat et al. 2008, Nardini et al. 2011, van Doorn et al. 2011), there is no clear evidence for the presence of pectins in PM for most angiosperms. Exceptions would be for gymnosperm and a few angiosperm species having pits with torus and pseudo-tori, respectively. However, studies were mostly performed using dyes that lack sensitivity and accuracy, yet were not sufficient to exclude a role of pectins in PM swelling and shrinking properties (van Doorn et al. 2011). Accurate, specific and sensitive immunogold labeling showed that pectins are absent from most of the PM but that clustered in the PM annulus in poplar and other angiosperm species having homogeneous pits (Plavcova et al. 2011, Plavcova and Hacke 2011). This annulus is a conspicuous feature of the PM, and for the investigated species, the pectins were found to be more concentrated in this annulus than in the other part of the cell wall. Taken together, these studies and our findings suggested that pectin concentrated in the PM annulus would be involved in VC, at least for poplar. This restricted localization of pectins fits well with the lack of effect of pectin hydrolysis on hydraulic conductance.

\section{Hydraulic functions of PM}

Our results point to the conclusion that the safety and efficiency functions of PM, i.e. VC and hydraulic conductance, are uncoupled. The uncoupling of these two PM functions was also evidenced by an effect of sap ionic composition on conductance but not on VC (Cochard et al. 2010). Intriguingly, pectin hydrolysis did not seem to change PM structure or porosity, despite fairly high $P_{50}$ values in beech and poplar. According to Laplace's law, beech PM would need a pore diameter of $0.91 \mu \mathrm{m}$ to allow air seeding under $-0.32 \mathrm{MPa}$. Our TEM observations were unable to find any hole in the pectolyase-treated PM. Using TEM, smaller holes with a mean diameter of $0.051 \mu \mathrm{m}$ were observed in PM from different conifer species and fitted well with the pressure needed to explain their VC (Jansen et al. 2012). We can thus rule out that the TEM was unsuitable for investigating large pores in PM. When a pit allows water flow from one sap-filled vessel to another, the pressure differential across the PM is very small. In this situation, the PM is in relaxed state, and cellulose offers the main pit resistance to sap flow as it is the main component. Here, only cellulose hydrolysis led to an increase in conductance, related to a complete breakdown of the PM. When the pit has to block air seeding from an air-filled vessel to a sap-filled vessel, there is a much bigger pressure differential (several MPa) across the PM. The PM thus gets stretched and deformed, and so VC would be dependent on the mechanical resistance of the pit (Choat et al. 2004, Sperry and Hacke 2004, 2008). The resulting VC would be a function of pit geometry and intrinsic PM properties. Pit geometry includes the PM thickness involved in both hydraulic efficiency and safety (Sperry and Hacke 2004, Lens et al. 2011). Pectin properties were critical for the mechanical properties of the cell wall, especially for wall extensibility (Chanliaud et al. 2002, Parre and Geitmann 2005, Pelloux et al. 2007). Pectins could thus contribute to the intrinsic mechanical properties of the PM.

Pectin hydrolysis, like calcium removal, had an effect on VC but not on conductance, whereas sap ionic concentration had an effect on conductance but not on VC (Cochard et al. 2010). The ionic effect on conductance cannot be due to the hydrogel properties of pectins, as was initially proposed by Zwieniecki et al. (2001), at least for beech and poplar and maybe most of angiosperms species. Our results are in agreement with the alternative hypothesis proposed by van Doorn et al. (2011) that the ionic effect can be attributed to any other polyelectrolyte of the PM. Hemicelluloses can be ruled out, since their hydrolysis had no effect on conductance. Two microspectrometry studies showed that there is lignin in PM for various species (Boyce et al. 2004, Schmitz et al. 2008). Hence, cellulose remains the best candidate for regulating the xylem conductance, while a role for lignins has to be addressed.

Acknowledgements - The authors thank Christelle Blavignac and Claire Szczepaniak from the CICS (Centre Imagerie Cellulaire Santé) platform (Clermont-Ferrand, France) for running the TEM analyses. This research was funded by the PitBulles project (ANR No. 2010 Blan 171001).

\section{References}

Alder NN, Pockman WT, Sperry JS, Nuismer S (1997) Use of centrifugal force in the study of xylem cavitation. J Exp Bot 48: 665-674 
Alves E, Leite B, Pascholati S, Ishida M, Andersen P (2009) Citrus sinensis leaf petiole and blade colonization by Xylella fastidiosa: details of xylem occlusion. Sci Agric (Braz.) 66: 218-224

Awad H, Barigah T, Badel E, Cochard H, Herbette S (2010) Poplar vulnerability to xylem cavitation acclimates to drier soil conditions. Physiol Plant 139: 280-288

Boyce CK, Zwieniecki MA, Cody GD, Jacobsen C, Wirick S, Knoll AH, Holbrook NM (2004) Evolution of xylem lignification and hydrogel transport regulation. Proc Natl Acad Sci USA 101: 17555-17558

Butterfield BG, Meylan BA (1982) Cell wall hydrolysis in the tracheray elements of the secondary xylem. In: New perspectives in wood anatomy. Springer, Netherlands, pp $71-84$

Catesson A (1983) A cytochemical investigation of the lateral walls of Dianthus vessels. Differentiation and pit-membrane formation. IAWA Bull 4: 89-101

Chanliaud E, Burrows KM, Jeronimidis G, Gidley MJ (2002) Mechanical properties of primary plant cell wall analogues. Planta 215: 989-996

Chappell J, VonLanken C, Vögeli U (1991)

Elicitor-inducible 3-hydroxy-3-methylglutaryl coenzyme A reductase activity is required for sesquiterpene accumulation in tobacco cell suspension cultures. Plant Physiol 97: 693-698

Choat B, Jansen S, Zwieniecki MA, Smets E, Holbrook NM (2004) Changes in pit membrane porosity due to deflection and stretching: the role of vestured pits. J Exp Bot 55: 1569-1575

Choat B, Brodie TW, Cobb AR, Zwieniecki MA, Holbrook NM (2006) Direct measurements of intervessel pit membrane hydraulic resistance in two angiosperm tree species. Am J Bot 93: 993-1000

Choat B, Cobb AR, Jansen S (2008) Structure and function of bordered pits: new discoveries and impacts on whole-plant hydraulic function. New Phytol 177: 608-625

Choat B, Jansen S, Brodribb TJ, Cochard H, Delzon S, Bhaskar R, Bucci SJ, Feild TS, Gleason SM, Hacke UG, Jacobsen AL, Lens F, Maherali H, Martinez-Vilalta J, Mayr S, Mencuccini M, Mitchell PJ, Nardini A, Pittermann J, Pratt RB, Sperry JS, Westoby M, Wright IJ, Zanne AE (2012) Global convergence in the vulnerability of forests to drought. Nature 491: 752-755

Cochard H (2002) A technique for measuring xylem hydraulic conductance under high negative pressures. Plant Cell Environ 25: 815-819

Cochard H (2006) Cavitation in trees. C R Physique 7: 1018-1026

Cochard H, Cruiziat P, Tyree MT (1992) Use of positive pressures to establish vulnerability curves: further support for the air-seeding hypothesis and implications for pressure-volume analysis. Plant Physiol 100: 205-209
Cochard H, Casella E, Mencuccini M (2007) Xylem vulnerability to cavitation varies among poplar and willow clones and correlates with yield. Tree Physiol 27: $1761-1767$

Cochard H, Holtta T, Herbette S, Delzon S, Mencuccini M (2009) New insights into the mechanisms of water-stress-induced cavitation in conifers. Plant Physiol 151: 949-954

Cochard H, Herbette S, Hernandez E, Holtta T, Mencuccini M (2010) The effects of sap ionic composition on xylem vulnerability to cavitation. J Exp Bot 61: 275-285

Czaninski Y (1972) Observations ultrastructurales sur I'hydrolyse des parois primaires des vaisseaux chez le Robinia pseudo-acacia L. et I'Acer pseudoplatanus L. C R Acad Sci (Paris) 275: 361-363

Czaninski Y (1979) Cytochimie ultrastructurel des parois du xyleme secondaire. Biol Cell 35: 97-102

Dalla-Salda G, Martinez-Meier A, Cochard H, Rozenberg P (2009) Variation of wood density and hydraulic properties of Douglas-fir (Pseudotsuga menziesii (Mirb.) Franco) clones related to a heat and drought wave in France. Forest Ecol Manag 257: 182-189

van Doorn WG, Hiemstra T, Fanourakis D (2011) Hydrogel regulation of xylem water flow: an alternative hypothesis. Plant Physiol 157: 1642-1649

Dute R, Hagler L, Black A (2008) Comparative development of intertracheary pit membranes in Abies firma and Metasequoia glyptostroboides. IAWA J 29: 277-289

Fromm J, Rockel B, Lautner S, Windeisen E, Wanner G (2003) Lignin distribution in wood cell walls determined by TEM and backscattered SEM techniques. J Struct Biol 143: $77-84$

Gortan E, Nardini A, Salleo S, Jansen S (2011) Pit membrane chemistry influences the magnitude of ion-mediated enhancement of xylem hydraulic conductance in four Lauraceae species. Tree Physiol 31: 48-58

Hacke UG, Jansen S (2009) Embolism resistance of three boreal conifer species varies with pit structure. New Phytol 182: 675-686

Hacke UG, Sperry JS, Wheeler JK, Castro L (2006) Scaling of angiosperm xylem structure with safety and efficiency. Tree Physiol 26: 689-701

Harrak H, Chamberland H, Plante M, Bellemare G, Lafontaine J, Tabaeizadeh Z (1999) A proline-, threonine-, and glycine-rich protein down-regulated by drought is localized in the cell wall of xylem elements. Plant Physiol 121: 557-564

Herbette S, Cochard H (2010) Calcium is a major determinant of xylem vulnerability to cavitation. Plant Physiol 153: 1932-1939

Herbette S, Wortemann R, Awad H, Huc R, Cochard H, Barigah TS (2010) Insights into xylem vulnerability to 
cavitation in Fagus sylvatica L.: phenotypic and environmental sources of variability. Tree Physiol 30: 1448-1455

Imamura Y, Harada H, Saiki H (1974) Embedding substances of pit membranes in softwood tracheids and their degradations by enzymes. Wood Sci Technol 8: $243-254$

Jansen S, Sano Y, Choat B, Rabaey D, Lens F, Dute RR (2007) Pit membranes in tracheary elements of Rosaceae and related families: new records of tori and pseudotori. Am J Bot 94: 503-514

Jansen S, Choat B, Pletsers A (2009) Morphological variation of intervessel pit membranes and implications to xylem function in angiosperms. Am J Bot 96: 409-419

Jansen S, Lamy JB, Burlett R, Cochard H, Gasson P, Delzon S (2012) Plasmodesmatal pores in the torus of bordered pit membranes affect cavitation resistance of conifer xylem. Plant Cell Environ 35: 1109-1120

Lens F, Sperry JS, Christman MA, Choat B, Rabaey D, Jansen S (2011) Testing hypotheses that link wood anatomy to cavitation resistance and hydraulic conductivity in the genus Acer. New Phytol 190: 709-723

Maherali H, Pockman WT, Jackson RB (2004) Adaptive variation in the vulnerability of woody plants to xylem cavitation. Ecology 85: 2184-2199

Miller G (1959) Use of dinitrosalicylic acid reagent for determination of reducing sugar. Anal Chem 31 : 426-328

Nardini A, Salleo S, Jansen S (2011) More than just a vulnerable pipeline: xylem physiology in the light of ion-mediated regulation of plant water transport. J Exp Bot 62: $4701-4718$

O'Brien T, Timann K (1967) Observations on the fine structure of the oat coleoptile. III. Correlated light and electron microscopy of the vascular tissues. Protoplasma 63: $443-478$

O'Brien T (1970) Further observations on hydrolysis of the cell wall in the xylem. Protoplasma 69: 1-14

Pammenter NW, Vander Willigen C (1998) A mathematical and statistical analysis of the curves illustrating vulnerability of xylem to cavitation. Tree Physiol 18: 589-593

Parre E, Geitmann A (2005) Pectin and the role of the physical properties of the cell wall in pollen tube growth of Solanum chacoense. Planta 220: 582-592

Pelloux J, Rusterucci C, Mellerowicz EJ (2007) New insights into pectin methylesterase structure and function. Trends Plant Sci 12: 267-277

Pittermann J, Choat B, Jansen S, Stuart SA, Lynn L, Dawson TE (2010) The relationships between xylem safety and hydraulic efficiency in the Cupressaceae: the evolution of pit membrane form and function. Plant Physiol 153: 1919-1931

Plavcova L, Hacke UG (2011) Heterogeneous distribution of pectin epitopes and calcium in different pit types of four angiosperm species. New Phytol 192: 885-897

Plavcova L, Hacke UG, Sperry JS (2011) Linking irradiance-induced changes in pit membrane ultrastructure with xylem vulnerability to cavitation. Plant Cell Environ 34: $501-513$

Sano Y (2005) Inter- and intraspecific structural variations among intervascular pit membranes, as revealed by field-emission scanning electron microscopy. Am J Bot 92: 1077-1084

Schmid R, Machado R (1968) Pit membranes in hardwoods - fine structure and development. Protoplasma 66: 185-204

Schmitz N, Koch G, Schmitt U, Beeckman H, Koedam N (2008) Intervessel pit structure and histochemistry of two mangrove species as revealed by cellular UV microspectrophotometry and electron microscopy: intraspecific variation and functional significance. Microsc Microanal 14: 387-397

Schulte P, Gibson A (1988) Hydraulic conductance and tracheid anatomy in six species of extant seed plants. Can J Bot 66: 1073-1079

Sperry JS, Hacke UG (2004) Analysis of circular bordered pit function I. Angiosperm vessels with homogenous pit membranes. Am J Bot 91: 369-385

Sperry JS, Tyree MT (1988) Mechanism of water stressinduced xylem embolism. Plant Physiol 88: 581-587

Sperry JS, Hacke UG, Wheeler JK (2005) Comparative analysis of end wall resistivity in xylem conduits. Plant Cell Environ 28: 456-465

Tissier J, Lambs L, Peltier J, Marigo G (2004) Relationships between hydraulic traits and habitat preference for six Acer species occurring in the French Alps. Ann For Sci 61: 81-86

de Vries RP, Visser J (2001) Aspergillus enzymes involved in degradation of plant cell wall polysaccharides. Microbiol Mol Biol Rev 65: 497-522

Wheeler JK, Sperry JS, Hacke UG, Hoang N (2005) Inter-vessel pitting and cavitation in woody Rosaceae and other vesselled plants: a basis for a safety versus efficiency trade-off in xylem transport. Plant Cell Environ 28: 800-812

Wortemann R, Herbette S, Barigah TS, Fumanal B, Alia R, Ducousso A, Gomory D, Roeckel-Drevet P, Cochard H (2011) Genotypic variability and phenotypic plasticity of cavitation resistance in Fagus sylvatica L. across Europe. Tree Physiol 31: 1175-1182

Zwieniecki MA, Melcher PJ, Holbrook NM (2001) Hydrogel control of xylem hydraulic resistance in plants. Science 291: 1059-1062

Edited by M. Oliver 